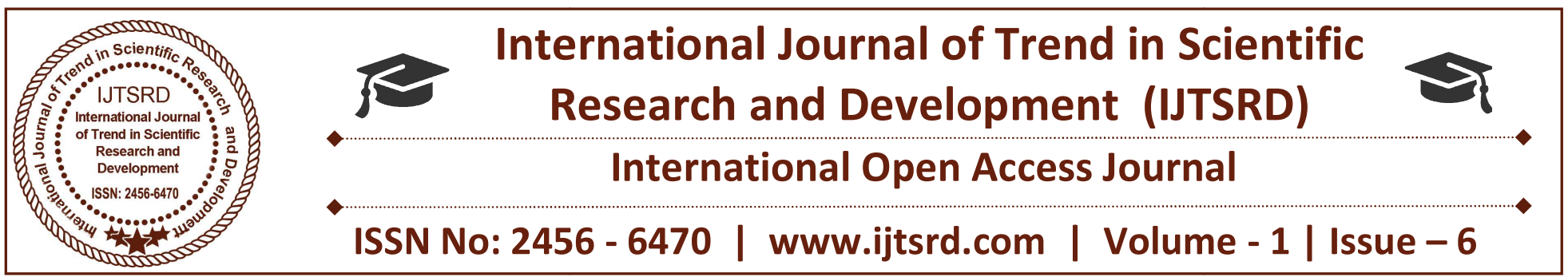

\title{
Human Resource Development: A Conceptual Exposition
}

\author{
Tirumala Rao Guruvu \\ Research Scholar in Department of Management, \\ Rayalaseema University, Kurnool, Andhra Pradesh
}

\begin{abstract}
Development of persons to their maximum potential and the conservation of talent is the Human Resource Development (HRD) concept. HRD has been defined as "the process of increasing the knowledge, skills and the people in society". But today, there is a little awareness of the fact that HRD is a contributing factor for the economic growth of the country. Without qualitative improvement of human resource the possibilities of an improvement in the standard of living of the masses are remote. An organization is known not by concrete and bricks but by the type of its human resource. It is constructed or destroyed by quality and behavior of its people. It has growingly been realized that improvement in manpower in key to both micro and macros developers.
\end{abstract}

\section{INTRODUCTION}

Human Resource Development is said to be the care of a larger system known as human resource system and HRD is mainly concerned with providing learning experience for the people associated with an organization through a behavioral approach adopting various processes. The individual is provided with learning experiences not in isolation but shares others learning experiences also. Such learning experiences are provided with the main objective of developing human beings for their advantage and producing their powerful physical, mental and intellectual endowments and abilities for the growth of organization.

In a broader scene, the term HRD means those learning experiences which are organized for a

specific time and designed to bring about the possibility of behavioral change. Human Resource Development in the organization context refers to the process whereby the workers are continuously helped in a planned way to -

a) Acquire or sharpen capabilities required to perform various tasks and functions associated with their present or future expected roles.

b) Develop their general enabling capabilities as individuals so that they are able to discover and exploit their own inner-potential for their own and/ or organizational development purposes and

c) Develop an organizational culture where 'superior/ subordinate' relationships, 'teamwork' and 'collaboration' among different subunits, which are strong and contribute to the professional well-being, motivation and pride of work.

In the area of HRD we can continuously develop the people so that, they are competent managers and competent workers and committed to the organizational goals. With growing importance of HRD movement, there has been significant increase in training programme budgets in the organizations. This trend is very noticeable, as many medium and even smaller sized organizations have begun to initiate training programmes. The workers training through HRD activities is not only the process of developing skills of workers; but it is the process of changing attitudes of the workers by involving them into improving the activities 
They carry out. This encompasses timely and value added management acts as way of life. The focus of HRD through training is essentially on enabling workers to self actualize through a systematic process of developing their existing potentialities and creating a new ones; unfolding and tapping potentials, capabilities of workers both in the present and for future.

The changes that have taken place in the past few years all over the world have established very clearly that no Nation can isolate itself completely form the rest of the world and survive for too long a time. The new economic policies have pushed India into the race for globalization. The new economic environment has significance to all, of first as citizens of India, next as responsible businessmen, leaders, managers, workers as well as providers of services. If the country has to get the best from the economic policies; we all have to give our best and also get the best from each other. Every profession, discipline and function should contribute to make this happen. Here HRD has a special responsibility as it deals with the people.

From the above discussion it is clear that, HRD is the total knowledge, skill, creative abilities, talents and aptitudes of an industrial workforce as well as the values, attitudes of an individual involved. It is the sum total of inherent ability, acquired knowledge and skill represented by the talents and aptitudes of the employed persons. HRD at organizational level includes, carrying out manpower research and planning to anticipate long term labour market needs, manpower development through training programmes, manpower distribution through an effective placement service and manpower utilization of assure of utilization of the nation's human resources. HRD at the organizational level is a process by which workers of an organization are helped in a systematic and continuous way. Thus, HRD is continuous process and comprehensive system by itself. That is why every management has to develop its workforce in order to develop the organization. HRD in its turn, almost entirely depends upon workers training, management, and development.

\section{REFERENCES:}

1) Deb,T. (2010), "Human Resource Development Theory and Practices", Ane Books Pvt. Ltd, New-Delhi, pp. 27, 33, 30, 19, 20, 21, 22, 23, 24, $25,26,40,97,95,94,96,42,43$.
2) Gupta, C.B., (2003), "Human Resource Management" S.Chand and Sons, New- Delhi p. 3.51 .

3) Gupta, S. and Gupta, S., (2008), "HRD Concepts and Practices" Deep and Deep Publication Pvt.ltd, New-Delhi.

4) Kelly D. (2001), "Dual Perceptions of HRD: Issues for Policy: SME's, Other Constituencies, and the Contested Definitions of Human Resource Development", http://ro.uow.edu.au/artspapers/26

5) Khan, M.N., (1987), "HRD in Modern Technological Structure" Indian Journal of Commerce, XL No. 150-51, p. 83.

6) Khurana, A., Khurana, P. and Sharma, H.L., (2009), "Human Resource Management", V.K.Enterprises, New Delhi.

7) Matthews, J.J., Megginson, D. and Surtees, M., (2004), "Human Resource Development" Kogan Page India Pvt Ltd, p. 14.

8) Megginson, L.C., (1982), "Personnel and Human Resource Administration" Homewood III: Richard D.Irwin, p.6.

9) Pareek, U and Rao, T.V., (1981) "Designing and Managing Human Resource Systems" Oxford IBH, New- Delhi.

10) Pattanayak, B. (2005), "Human Resource Management" Prentice Hall of India Pvt ltd, New- Delhi, p. 106,

11) Prasad, L.M., (2009), "Human Resource Management" S.Chand and Sons, New Delhi, p. 332.

12) Rao T.V. and Pereira, D.F., (1986), "Recent Experiences in HRD" Oxford and IBH Publishing Co. Pvt.ltd.

13) Rao V.S.P., (2005, $\left.2^{\text {nd }} E d\right)$, "Human Resource Management" Excel Books, New- Delhi. pp. 269, 272,273, 271, 276, 272,273, 274.

14) Sheikh, A.M. (2009), "Human Resource Development and Management" S.Chand and Co. 1td, New- Delhi, pp.79-80.

15) Sofo, (1999), "Human Resource Development", Business and Professional Publishing, Warriewood.

16) Tripathi, P.C., (1997), "Human Resource Development" Sultan Chand and Sons, New Delhi, p.5. 